\title{
SĄVEIKOS SAMPRATOS KAITA LIETUVOS EDUKOLOGŲ DARBUOSE
}

\author{
Aldona Palujanskienè \\ Lietuvos žemès ūkio universitetas, Kaunas, Lietuva
}

\begin{abstract}
Aldona Palujanskienė. Lietuvos žemės ūkio universiteto Profesinės pedagogikos ir psichologijos katedros docentė. Mokslinių tyrimų kryptis — asmenybès vystymasis ir pedagoginė sąveika.
\end{abstract}

\section{SANTRAUKA}

Tradicinis mokymas jau nèra veiksmingas. Mokiniai rengiami ateičiai, kuri šiandien sunkiai nuspejjama ir pareikalaus iš ju ne tik nuolatinio mokymosi, bet ir nuolatinio kūrybiškumo, nes iggytos žinios greitai kintančioje socialinëje aplinkoje negarantuoja mokiniu permanentinès kokybiškos socialinès adaptacijos. Mokymosi paradigmos kontekste mokytojas - mokymosi konsultantas, savo žinias ir igūdžius taikantis mokiniui, padèdamas jam ìveikti problemas, kurios kyla besimokant, o pats mokinys aktyviai dalyvauja tobulindamas ir keisdamas mokymo turini. Lietuvos mokyklos nesékmé yra ta, kad ji nesudaro galimybiu mokiniams pajusti ir suprasti objektu, ¿̇vykiu ir žiniu asmeninio reikšmingumo, o patys mokiniai mokykloje vis dar jaučia baimę, nerima, nevisavertiškumq. Visa tai skatina peržiūrèti ir praplèsti ugdomosios sqveikos paradigma išsamesniu mokiniu psichikos ir besiformuojančios asmenybès ypatybiu pažinimo bei didesnio mokytoju profesionalumo aspektu. Taigi edukacinès paradigmos virsmas iš mokymo $i$ mokymąsi susiduria su nelauktais iššūkiais - ne tik su edukaciniu aplinku kūrimu, bet ir asmens menku suinteresuotumu, nusiteikimu visur ir visada sužinoti kq nors nauja ir kryptingai visomis įmanomomis formomis ir büdais mokytis ne tik specialioje edukacinejje aplinkoje, bet ir apskritai gyvenime. Suprasdami sudètinga mokymo paradigmos virsmo i mokymosi paradigma procesq pedagoginèje praktikoje, mokslininkai (Jucevičienè, Petkūnas, 2006; Ciužas, 2007; Jucevičiené, 2007; Jucevičiené, Valuckiené, 2008) nagrinèja sqveikos paradigma, kuri savo pedagoginèmis nuostatomis ir ugdymo turiniu artima mokymosi paradigmai. Anot P. Jucevičienès, sqveikos paradigma „pripažista laisvesnes ugdymo pozicijas nei mokymo, tačiau ji „,kietesne“ nei mokymosi paradigma“(2007, p. 109). Cia mokytojas priima sprendima dèl ugdymo turinio, bet kartu su mokiniu (mokiniais) nusprendžia, kaip bus mokoma. Minèti autoriai akcentuoja sqveikq metodu pasirinkimo prasme, tačiau tada kyla klausimas o ar sqveikos paradigma gali būti grindžiama tik laisvu metodo pasirinkimu, ar nèra daugiau veiksniu, ypač susijusiu su sqveikos dalyviais (pedagogu ir mokiniu), labiau priartinančiu sqveikos paradigma prie mokymosi paradigmos?

Apžvalgos tikslas - susisteminti ugdomosios sqveikos tema parašytus Lietuvos edukologu tyrimus ir atskleisti sqveikos paradigmos taikymo papildomas galimybes. Tikslui pasiekti keliami uždaviniai: 1) apibūdinti ugdomaja sqveika; 2) apibrëžti pagilinta ugdomosios squeikos samprata remiantis šiame straipsnyje aptariamais tyrimais. Tyrimo metodas - mokslinès literatūros analizè.

Šio apžvalginio straipsnio antroje dalyje aptariami A. Palujanskienès ir kitu straipsniai pagilino sqveikos kaip dvasinio pakilimo būsenos samprata psichopedagoginiu sqlygu, kurioms esant toks pakilimas turètu atsirasti, analize. Atskleista, kad ugdomoji sqveika — specifinis tikrovés reiškinys, kurị dera pažinti, atskleisti, taikyti (Bitinas, 1990). Tai pereinamasis momentas iš mokymo paradigmos į mokymosi. Tai asmenybès ruošimas saviugdai, kai žmogus, įsivertinęs save ir savo galimybes, pats nusistato tobulëjimo krypti, pats išsikelia ugdymosi tikslus, pasirenka priimtinus büdus ir priemones, aktyviai siekdamas tikslo plečia žinojima, ji praturtindamas visokeriopa gyvenimiška patirtimi.

Ugdomaja sqveika galima Ł̇vardyti kaip sqveikos dalyviu tarpusavio suvokima ir supratima per ju individualiqsias savybes, nuostatas, būsenas ir kaip nenutrūkstamq pedagoginiu situaciju sekq, kur ir vienu, ir kitu atveju sqveika ivyks, kai jos dalyviai tiek pažins ir supras vienas kita, kad tarp ju kils savotiška dvasinio pakilumo būsena. Taigi ugdomoji squeika nagrinèjama ir aiškinama ugdymo psichologijos žiniomis, nes, kaip teigia B. Bitinas, „edukologija dar nepasirengusi modeliuoti ugdytojo ir ugdytinio sqveikos kaip save reguliuojančios sistemos, ir situacija analizuojama ugdymo psichologijos išvadomis “ (2006, p. 65, 64).

Raktažodžiai: squeikos paradigma, pedagogo ir mokinio squeika, interaktyvūs metodai, mokinio pažinimas, pedagogo profesionalumas.

\section{IVADAS}

$\mathrm{M}$ okytojo gyvenimo prasmès paiešku kontekste ryškejja tai, kad greta dalyko, didaktikos kompetencijos i pirmą vietą turi iškilti socialinè-emocinè inteligencija, asmenybės branda, praktinis ir psichologinis parengtu- mas prasmingai susitikti su įvairiais ugdytiniais, jų tèvais ir bendraamžiais (Merkys, 2006). Tai skatina peržiūrèti ir praplèsti ugdomosios sąveikos paradigmą išsamesniu mokiniu psichikos ir besiformuojančios asmenybès ypatybių pažinimo 
bei didesnio mokytojų profesionalumo aspektu. Suprasdami sudètingą mokymo paradigmos virsmo i mokymosi paradigmą procesą pedagoginèje praktikoje, mokslininkai (Jucevičienè, Petkūnas, 2006; Čiužas, 2007; Jucevičienè, 2007; Jucevičienè, Valuckienè, 2008) nagrinèja sąveikos paradigmą, kuri savo pedagoginèmis nuostatomis ir ugdymo turiniu artima mokymosi paradigmai. Anot P. Jucevičienės, sąveikos paradigma „pripažista laisvesnes ugdymo pozicijas nei mokymo, tačiau ji „kietesne்“ nei mokymosi paradigma“ (2007, p. 109). Čia mokytojas priima sprendimą dèl ugdymo turinio, bet kartu su mokiniu (mokiniais) nusprendžia, kaip bus mokoma. R. K. Branson (1990) nurodo tris sistemos kaitą išreiškiančius mokymo, sąveikos ir mokymosi modelius, kuriais, pradedant antruoju (sąveikos), mokiniai sąveikauja su mokytoju ir tarpusavyje ugdymo priemoniu, formų ir metodų prasme, t. y. mokiniai patys renkasi mokymo - mokymosi metodą (interaktyvūs mokymo - mokymosi metodai) ir taip tarsi pasiruošia mokymosi paradigmai, kur mokiniu žinios bei patirtis veikia ir pati mokytoja, nes informacinès bazès ir eksperimentinès sistemos vienodai prieinamos ir vieniems, ir kitiems. Minèti autoriai akcentuoja sąveiką metodų pasirinkimo prasme, tačiau tada kyla klausimas, ar sqveikos paradigma gali būti grindžiama tik laisvu metodo pasirinkimu, ar nèra daugiau veiksniu, ypač susijusiu su sqveikos dalyviais (pedagogu ir mokiniu), labiau priartinančiu squeikos paradigma prie mokymosi paradigmos?

Apžvalgos tikslas - susisteminti ugdomosios sąveikos tema parašytus Lietuvos edukologu darbus ir atskleisti sąveikos paradigmos taikymo papildomas galimybes. Tikslui pasiekti keliami uždaviniai: 1) apibūdinti ugdomają sąveiką; 2) apibrèžti pagilintą ugdomosios sąveikos sampratą remiantis šiame straipsnyje aptariamais tyrimais.

Tyrimo metodas - mokslinès literatūros analizè.

1. Ugdomosios sąveikos samprata. Anot V. Jakavičiaus (1998), sąveika yra vidinè ugdymo dalis, lemianti išorinę komunikaciją ir jos rezultatus. Ji neužsimegs, jei ugdytojas nemokès savimi sukelti ugdytinio noro bendrauti.

„Pedagoginè sėkmé priklauso ne tik nuo ugdytinio pažinimo, bet ir nuo to, kaip ugdytojas geba pažinti savo ugdytinio grižtamaji poveiki ir atitinkamai koreguoti savaji, skatinant ugdytini veikti norima linkme“ (Jakavičius, Juška, 1996, p. 59). Taigi sqveika buvo suprantama kaip keitimasis veiksmais ir tarpusavio poveikiu, tarpusa- vio suvokimu ir supratimu, o svarbiausi sqveikos veiksniai - ugdytoju ir ugdytiniu individualiosios savybès, socialinès nuostatos ir psichinès būsenos L. Jovaiša rašè, kad pedagoginę sąveiką galima laikyti ugdomaja, kuri yra grindžiama mokymo ir auklèjimo turiniu, o ją lemia pagal sąveikos dalyvių psichines savybes pasirinkti ugdymo metodai ir organizacinès formos (Jovaiša, 1993). B. Bitinas manè, kad kiekviena ugdomoji situacija yra sqvei$k a$. „Sąveika - objektyvios tikrovės reiškinys: ji egzistuoja ten, kur vienas asmuo sistemingai veikia siekdamas tobulinti kito asmens dvasini pasauli ir ši tobulinima grindžia grižtamaja informacija apie veiklos efektyvuma“" (1995, p. 5). Ugdomają sąveiką kaip kelių tarpusavyje susijusiu procesu visumą kai keičiamasi ne tik informacija, bet ir vienas kito nuotaika, jausmais interpretavo N. Bižys, G. Linkaitytè, A. Valiukevičiūtė (1992). Sąveika ugdymo procese - ne tik keitimasis veiksmais ir tarpusavio poveikiu, bet ir „tarpusavio suvokimas ir supratimas“ (Večkienė ir kt., 1998). Jos praplètė V. Jakavičiaus ir A. Juškos minti, kad negalima sąveiką ugdymo procese suprasti tik kaip „keitimąsi veiksmais ir tarpusavio poveikiu“, tai tikrai yra tarpusavio suvokimas ir supratimas (Večkienè ir kt., 1998, p. 125). Jos tarsi plètojo G. Butkienès ir A. Kepalaitès (1996) pastebėjimą kad klasikinė didaktika orientuota tik i mokytoją, kuris ugdo vaiką, o mokymo turinys nukreiptas daugiau $\mathfrak{i}$ rengima profesijai, o ne $i$ asmenybès ugdyma. Sąveika - bendrai veikiančių individų savitarpio pagalba tampanti kooperacija, o trikdis — konkurencija (Jacikevičienè, Rupšienè, 1999). Tačiau ar pakanka mokytojo instruktoriaus? Ar mokytojas vienas pats, formuluodamas mokymo tikslą, ugdo mokiniu gebejjimą dirbti grupejje? L. Jovaiša sąveiką interpretavo kaip abipusi veikima derinant veiksmus, kur praktinis veikimas yra vienas $i$ kita nukreipta veikla (tai pedagoginè sqveika). Ši sqveika priklauso nuo dalyviu santykiu glaudumo ir atitinkamu gebejjimu. Vadinasi, sqveika yra ir psichinis bendravimo mechanizmas, ir praktine bendravimo forma. Būtina pedagoginès sqveikos salyga - subjektu dvasinis pakilimas, transcendentine pedagoginio susitikimo būsena (Jovaiša, 2002). E. Martišauskienė pedagoginę sąveiką aprašè kaip asmens dvasinių galių savikūros pamatą (Martišauskiené, 2004; 2006). Aukščiausias sąveikos taškas būna tada, kai ugdytojas atskleidžia savąsias vertybes, kad „ugdytinis galètų su tomis vertybėmis susilieti“ (Martišauskienė, 2004, p. 110). Anot šios mokslininkès, pedagoginè squeika - tai ypatingas sqveikos dalyviu bendradarbiavimas, 
Lentelè. Sąveikos sampratos kaita

\begin{tabular}{|c|c|c|c|}
\hline Mokymo paradigma & \multicolumn{2}{|c|}{ Sąveikos paradigma } & Mokymosi paradigma \\
\hline $\begin{array}{l}\text { Sąveikos paradigmos užuomaz- } \\
\text { ga - mokymo grižtamasis ry- } \\
\text { šys (Bižys ir kt., 1992; Jovaiša, } \\
\text { 1993; Bitinas, 1995; Jakavičius, } \\
\text { Juška, 1996; Jakavičius, 1998). }\end{array}$ & $\begin{array}{l}\text { Komunikacija - sąveika } \\
\text { vyksta tarp mokytojo ir mo- } \\
\text { kinio, mokinio-mokinių } \\
\text { per interaktyvius moky- } \\
\text { mo-mokymosi metodus, } \\
\text { per tarimąsi, kaip mokinys } \\
\text { nori mokytis (Butkienè, } \\
\text { Kepalaitė, 1996; Večkienè } \\
\text { ir kt., 1998; Jacikevičienė, } \\
\text { Rupšienė, 1999). }\end{array}$ & $\begin{array}{l}\text { Dvasinis subjektu pakilimas, } \\
\text { transcendentinė pedagoginio } \\
\text { susitikimo būsena, ugdytojo } \\
\text { vertybių atskleidimas ugdyti- } \\
\text { niui, vertybiųinternalizavimas. } \\
\text { Pedagoginis susitikimas - } \\
\text { ugdomoji situacija (Jovaiša, } \\
\text { 2002; Šiaučiukėnienė, Stanke- } \\
\text { vičienė, 2002; Martišauskienė, } \\
\text { 2004; Aramavičiūtė, 2005; Bi- } \\
\text { tinas, 2006; Jovaiša, 2007). }\end{array}$ & $\begin{array}{l}\text { Mokinio galimybė rinktis, mo- } \\
\text { kinio savarankiškumas, atsako- } \\
\text { mybė už mokymąsi, mokinio } \\
\text { ir mokytojo galimybė patirti } \\
\text { džiaugsmą. Mokinys aktyviai } \\
\text { dalyvauja tobulindamas ir keis- } \\
\text { damas save, taiko savo draugu } \\
\text { patirti. Mokytojas - mylintis } \\
\text { konsultantas, žinių transformuo- } \\
\text { tojas i dalyko supratimą (Šiau- } \\
\text { čiukėnienė ir kt., 2006; Marti- } \\
\text { šauskienė, 2006; Jucevičienė, } \\
\text { Petkūnas, 2006; Jucevičienè, } \\
\text { 2007; Pudinaitė, 2007; Čiužas, } \\
\text { 2007; Jucevičienė, Valuckienė, } \\
\text { 2008). }\end{array}$ \\
\hline
\end{tabular}

kurio esmè ne tik tai, kad ugdytinis internalizuoja ugdytojo atskleistas vertybes, bet ir su jomis susilieja. V. Aramavičiūtè pratęsė E. Martišauskienès sąveikos sampratą. Sąveikos esmè - vertybiu internalizacija (Aramavičiūtè, 2005, p. 45). Pedagoginès sąveikos sampratą reikšmingai plètojo L. Šiaučiukènienè (Šiaučiukènienè, Stankevičienè, 2002; Šiaučiukènienè ir kt., 2006) pedagoginę meilę suprasdama kaip ne tai, kas atsiranda squeikos metu, o tai, kas nulemia norq pačiam ugdytojui ir pačiam ugdytiniui tobuletti. B. Bitinas ugdomają sąveika interpretavo kaip auklèjimo proceso esmę. Sąveika fiksuojama kaip įvykis, kaip pedagoginis susitikimas, kaip ugdymo aktas. Sąveika vyksta atviro ugdytojo ir ugdytinio dialogo metu, kai ugdomasis bendradarbiauja su savimi ir kitais. Nors B. Bitinas išskyrè ugdytinių vidini dominuojanti reorganizavimą (rekonstrukcini, konstrukcini, konformistini, indiferentinį ir konfliktinį), tačiau jis teigè, kad ugdomujų situacijų nenutrūkstamoje grandinèje „edukologija dar nèra pasirengusi modeliuoti ugdytojo ir ugdytinio sąveikos kaip save reguliuojančios sistemos“ (2006, p. 65). Taigi ugdomoji sqveika kaip ugdomoji situacija analizuojama ugdymo psichologijos išvadomis.

J. Pudinaitè (2007, p. 281-303) gilinosi į mokytojo-mokinio sąveikos sąlygas, kur be ivvairiu mokymo-mokymosi metodu, palankios aplinkos kaip tinkamo bendravimo išskiria motyvaciją (galimybę rinktis, sèkmės tikimybę, galimybę patirti džiaugsma, iššūkius). Saveikos sampratos kaita apibendrinama lentelèje.

Nors ir galima išskirti du sąveikos paradigmos kaitos etapus, tačiau minètų mokslininkų darbai nelèmė sąveikos kaip dvasinio subjektų pakilimo praktinio realizavimo galimybių, nes nebuvo er- dvès psichologinei sąveikos gilumai analizuoti. Kitame skyriuje ir yra pateikiamos ugdomosios sąveikos kaip subjektu dvasinio pakilumo psichopedagoginès sąlygos.

2. Ugdomoji sąveika kaip sąveikos dalyvių psichikos pažinimas ir nenutrūkstama pedagoginių situacijų seka. Švietimo reformos koncepcijoje numatoma, kad būtina sukurti diferencijuoto švietimo sistemą, sudarančią sąlygas asmeniui rinktis amžiaus tarpsni, individualius psichologinius ypatumus ir gebėjimų lygi atitinkantį ugdymo turini bei metodus, atitinkamas ugdymo programas ir atitinkamo profilio švietimo instituciją. Kita vertus, ugdytojas, geriau pažindamas savo ugdytinio vystymosi problematiką, gali daryti apgalvotą poveiki, taikydamas kūrybiškumą skatinančius ugdymo metodus, taip organizuodamas ugdomają aplinką, kad joje susidarytų kaip įmanoma mažiau sąlygu, pavyzdžiui, prasiveržti paauglių agresyvumui ar mokyklinio amžiaus vaikui pasijusti bijančiu, nerimastingu. Pedagogas šiandien suvokiamas kaip mokyklos organizacijos narys, ipareigotas atlikti ugdymo veiklą taip, kaip reikalauja curriculum, tačiau nepamirštantis, kad jis rengia žmogu „ateičiai, ìvairiais amžiaus tarpsniais plètojant gyvenimiškus gebejjimus ir skatinant kiekvieno savigarbą bei savo vertės pajautimą“ (Jucevičienè, 2007, p. 102).

Žurnale „Acta Peadagogica Vilnensia“ išspausdintame apžvalginiame straipsnyje „Vaiku psichologinės problemos“ ivertinta, kiek pykčio, nerimo, baimės išgyvenimu patiria moksleiviai, ir pagal tai įvertinta jų savijauta kaip gera ar bloga (Palujanskiené, 1999). Ugdomoji sąveika šiame kontekste pasireiškia kaip moksleivių suvokimas ir supratimas ivertinant dominuojančią moksleiviu 
būseną. Deja, didesnė dalis tirtų vaikų ịvardijami kaip „problemiški“: nustatytas mažas psichinis atsparumas, bloga savijauta, bejejgiškumo jausmas, agresyvumas. Mokytojams iškeliamas uždavinys mokèti ugdyti tokius vaikus, atkreipiant dèmesi $\mathfrak{i}$ tai, kad vaikai vystosi ir naujas amžiaus tarpsnis suteikia elgesiui naują formą, kur reikšminga nauja veikla, nauji santykiai su suaugusiaisiais, naujos proto išgalès, didinančios moksleiviu patyrimą ir mažinančios juc „problemiškumą“.

Be to, gvildenama ugdymo strategijos esmè užkirsti kelią plintančiai agresijai, mokyti vaikus ir jaunuolius konstruktyviai spręsti kilusius konfliktus (Palujanskienè, Uzdila, 2004). Šioje apžvalgoje aptariami agresyvumo ypatumai tarp paaugliu ir analizuojami agresyvumo tyrimų rezultatai, rodantys, kad dominuojanti agresijos forma - vidutinio laipsnio verbalinè agresija. Vadinasi, tarp mokinių paplitę kito izžeidinėjimas, grasinimas, šmeižimas. Nustatyta gana didelio pasireiškimo laipsnio agresija, nukreipta i save — tai rodo tirtu paauglių nepasitenkinimą savimi, abejojimą dèl savo pasirinkimų. Abiejų lyčių agresyvumas panašus, skiriasi formos - vaikinai linkę demonstruoti fizinę jègą prieš kitus, o tarp merginų nustatyta didesnè netiesioginè agresija „prieš daugelį kitų“. Nustatyta, kad konstruktyviai sprendžiantys konfliktus mokiniai konfliktinėmis situacijomis linkę kaltinti save (agresija nukreipta i save, be to, jiems būdinga mažiau išreikšta verbalinė agresija). Taigi ugdytojams siūloma ugdytinių agresyvumą mažinti mokant juos konstruktyviai spręsti iškylančius konfliktus. Tuo neapsiribojama: kitu tyrimu bandoma ieškoti ryšio tarp agresijos formos ir dominuojančios charakterio akcentuacijos (Palujanskienè, 2005). Siūlyta sąveikos dalyviams ugdytojams atkreipti demesi $\mathfrak{i}$ tai, kad ugdant paauglius prevencinės programos turi ne tik mažinti paaugliu netinkamo elgesio apraiškas, bet pozityviai veikti tokius paaugliu charakterio veiksnius, kurie susiję su paauglių psichine sveikata (pvz., netiesiogine agresija — priešiškumu — pasižymi labilumo akcentuacijas turintys abiejų lyčių paaugliai). Tiesioginė agresija (prieš žmogų, daiktą, verbalinė) pasireiškia abiejų lyčių atstovams esant ịvairioms charakterio akcentuacijoms.

Probleminių ir normalių šeimų paauglių asmenybės raida ivvertinta pagal Eriksono epigenetinę asmenybės vystymosi teoriją (Palujanskienè, 2002). Gauti geri raidos rezultatai tarp tiriamuju skatina ugdytoją ivvertinti tą fakta, kad šeima neegzistuoja socialiniame vaakume, o mokyklos vaidmuo formuojant paauglių adaptyviuosius igū- džius besikeičiančioje socialinėje aplinkoje išlieka dominuojantis.

Paauglių savijautos tyrimai leido nustatyti reikšmingus ugdomajai sąveikai dėsningumus geriau jaučiasi save pervertinantys jaunuoliai ir save adekvačiai vertinančios jaunuolès (Palujanskienè, 2003). Šiuo tikslu buvo siūloma sporto pedagogams taikyti diferencijuotus ugdymo ivertinimus: merginoms - teigiamo pastiprinimo metoda, vaikinams galima prognozuoti didesniu laimèjimų tikimybę ateityje, nes vaikinai elgsis taip lyg „norima“ jau yra „esama“.

Kitas ugdytinių ir ugdytojų sąveikos veiksnys - ugdytinių socialinès nuostatos kaip profesiniai lūkesčiai (Palujanskienè, Adamonienè, 2004). Nustatyta, kad ugdytojams tiek universitete, tiek profesinèje mokykloje gerai atliekant karjeros planavimo darbą ugdytinių profesiniai lūkesčiai keičiasi norima linkme - jie vis geriau ivvaldo asmeninę karjeros kompetenciją, daugiau iš savęs reikalauja, labiau pripažista profesini lankstuma kaip galimybę ateityje prisitaikyti prie kintančiu rinkos reikalavimų.

Ugdyti asmenybę - tai pasirūpinti valios išauklèjimu arba tokia asmens savireguliacija, kuri tarnautų ivairialypių poveikių selekcijai ir vertybių internalizacijai, kitaip tariant, garantuotu tinkamą ugdomają sąveiką (Uzdila, Palujanskienè, 2005). Pagilinta valios samprata turètu padèti ugdytojams geriau orientuotis kuriant ugdomają sąveiką, nes būtent vidinès žmogaus jègos ir galios tarnauja jo prigimties raidai, saviraiškai bei doroviniam tobulèjimui.

Ypač svarbi vidinė pedagogu motyvacija darbui (Palujanskienė, 2002). Teorinės problemos analizès ir tyrimų apibendrinimu pagrindu įrodoma, kad profesijos pedagogo saviraiška, tokia reikšminga ugdomajai sąveikai, be kurios turbūt ir neįmanomas sąveikos dalyvių dvasinis pakilimas, yra nulemta palankių sąlygų sudarymo pedagoginès veiklos pradžioje, pedagoginès kvalifikacijos kèlimo, išklausant įvairius pedagoginius kursus, tačiau toks poreikis nepriklauso nuo pedagoginio darbo stažo ir pedagogo amžiaus.

Tyrimais nustatyta dominuojančios mokytojų profesinès orientacijos ${ }^{1}$ - darbo stabilumo ir tarnavimo (Palujanskienè, Pugevičius, 2004). Tai

\footnotetext{
${ }^{1}$ Profesinès orientacijos nustatomos E. Schein testu. Apklausiamasis susidaro tam tikrą nuostatą apie tai, ko jis nori iš darbo, ir pagal tai toliau projektuoja savo karjerą. Pagrindinès orientacijos: profesinio meistriškumo, vadovavimo, autonomijos, saugumo, antrepreneriškumo, tarnavimo (paslaugos / atsidavimo), iššūkio, gyvenimo stiliaus.
} 
rodo, kad sąveikos dalyviai mokytojai linkę save realizuoti pašaukimo prasme, jiems yra priimtina mokyti ir rūpintis kitais (ugdytiniais). Darbo stabilumo karjera rodo, kad tyrimo dalyviai mokytojai yra atsargūs ir nelinkę priimti iššūkių.

Šią minti papildo 2007 metais atlikto tyrimo rezultatai (Palujanskiené, 2007). Nustatyta, kad labiausiai savo sėkme tiki iššūkio ir valdymo orientacijas pasirinkę déstytojai ir mokytojai. Be to, dėstytojai labiau tikisi profesinès sėkmės. Bendras tikèjimosi sèkme rezultatas yra vidutiniškas. Liūdina tai, kad tarnavimo orientaciją pasirinkę pedagogai patys netiki tuo, ką daro. Nors jie linkę save realizuoti profesineje veikloje, bet ypatingu rezultatų nelaukia.

Gvildenama ugdytoju kaip sąveikos dalyviu pasitenkinimo savo gyvenimu problematika (Palujanskienè, 2006). Pozityvus ịvykių, išgyvenimu vertinimas, teigiamu minčiu dominavimas nustatytas pusei tirtų respondentu, tačiau jausmas, kad daug kas priklauso nuo paties savęs (vidinis kontrolès lokusas nustatytas, kaip ir vilties jausmas, tik $6 \%$ pedagogiu). Idomu, kad beveik identiški rezultatai gauti kontrolinèje ekonomisčiu grupèje. Vidinių konfliktų nebuvimas ir harmoninga elgsena pasireikštu pasitenkinimo savo gyvenimu jausmu, deja, ištirta pedagogiu grupè to nejaučia. Ar gali nelaimingas (netikintis sèkme, nepatenkintas savo gyvenimu), nors ir norintis tarnauti ugdytiniams ir save realizuoti darbe pedagogas garantuoti kokybišką ugdomają sąveiką?

Ar nebus taip, kad tarpusavio santykių su ugdytiniu metu jis bandys išspręsti savo vidinius konfliktus, projektuodamas į ugdytini savo irzluma, netoleranciją ir kitas nepasitenkinimo išraiškas? Bet ir agresyvus, blogos savijautos, nepasitikintis ar pervertinantis save ugdytinis neatsitiktinai kuria su ugdytoju priešiškus santykius, kuriuos galima ivardyti „,agresija mokytojui“.

Minètas mintis papildo kitu tyrimų išvados (Mičiulienè, Palujanskiené, 2007). Nustatyta, kad mokytojai nemoka dirbti komandoje. Jie linkę dubliuoti vaidmenis, nelinkę rinktis kūrybiškuc idejjų generatoriaus ar kritiko vaidmenų, o ir pati mokytoju grupé, sudaryta projektinei veiklai, nepasižymi sutelktumu. Ar gali toks mokytojas sėkmingai bendradarbiauti, neprimesti savo nuomonès ugdytiniams, siūlydamas kad ir modernius ugdymo metodus ir formas? Juk šiuolaikinè didaktika siekia kurti palankų visiems ugdymąsi, jos tikslas ne priversti paklusti, o sudominti, aktyvinti kūrybines ir darbines galias, ji nukreipta $\mathfrak{i}$ besimokantiji, o mokytojas orientuotas į sutartinę veiklą planuojant, reflektuojant ir igyvendinant ją darnoje su mokiniu.

Straipsnyje „Aukštesniosios mokyklos kuratoriaus vaidmuo asmenybės raidoje“, atspausdintame 2003 m. „Pedagogikos“ žurnale, gilinamasi ị tai, koki ugdytoją norètų turèti aukštesniosios mokyklos ugdytiniai. Nors respondentai-ugdytiniai nurodo, kad kuratorius jiems reikalingas, bet nemato galimybiu, kad jis turètų itakos jų laisvalaikio praleidimui ar kuo nors realiai galètų padèti. Artimų santykių (pastarieji turètų peraugti į ugdomają sąveiką ir skatintų ugdytinius internalizuoti kuratorių perteikiamas vertybes) nenustatyta.

Ugdymą kaip holistinę sistemą realizuoja ugdomoji sąveika, o ją konkretina pedagoginiai santykiai ir pedagoginis bendravimas. Sąveika fiksuojama kaip įvykis, pedagoginis susitikimas, ugdymo aktas. Ugdomoji situacija visada individuali, besikartojanti tik savo esme. Kitaip tariant, sąveika - tai ugdytojo ir ugdytinio dialogas, kur ugdymasis - bendradarbiavimas su savimi ir kitais. Papildomą informaciją apie ugdomają sąveiką teikia ugdomujų situacijų analizè. Tokios situacijos yra išanalizuotos A. Palujanskienès straipsniuose „Vaiku adaptacija mokykloje“ (2006 m. žurnale „Socialinis ugdymas“) ir „Creativity As The Way of Humanization of The Pedagogical Process“ (2003 m. „Pedagogija: Teorija un Prakse“). Pirmame straipsnyje nagrinejjamos ugdomosios situacijos - vaikų adaptacija pradžios mokykloje ir penktoje klasejje. Sąveika vyksta tarp mokytojos su tik ką i mokyklą atėjusiu pirmaklasiu, ji kartojasi per visus pirmus mokslo metus įvairiomis formomis. Adaptacija vyksta sẻkmingai, jei pirmokai neatskleidžia didelio nerimastingumo, o patikimai sumažèjęs nerimastingumas antrų mokslo metu pradžioje laikomas sėkmingos sąveikos rezultatu. Metus palankę mokyklą vaikai mažiau bijosi kontrolinių darbu̧ jų savivertė padidẻja, sumažèja somatinių nerimastingumo požymių. Penktoje klasėje geriau adaptuojasi (mažesnis nerimo lygis) mokiniai, pradžios mokyklą baigę tos pačios gimnazijos pradinėje mokykloje. Kitas pedagoginès situacijos pavyzdys - paauglių kūrybiškumo didinimas meno mokykloje. Po daugkartinio paauglių piešinių vertinimo jų meninis kūrybiškumas pasidaro mažesnis nei tokio pat amžiaus aukštesniosios mokyklos ugdytinių.

\section{IŠVADOS}

Apibendrinant ugdomają sąveiką galima ịvardyti kaip sąveikos dalyvių tarpusavio suvokimą ir 
supratimą per jų individualiąsias savybes, nuostatas, būsenas ir kaip nenutrūkstamą pedagoginiu situacijų seka, kur ir vienu ir kitu atveju sąveika ivvyks, kai jos dalyviai tiek pažins ir supras vienas kita, kad tarp jų kils savotiška dvasinio pakilumo būsena.

- Lietuvos ugdymo mokslo ir praktikos probleminè patirtis leido ugdymo sąveikos paradigmą išplèsti jos kaitos požiūriu, o šios žinios gali praversti ir vakarų šalių ugdytojams, vis labiau susiduriantiems su ugdytinių individualizmu ir agresija.

- Tam, kad įvyktų ugdomoji sąveika Lietuvos pedagogai turi atsižvelgti į ugdytinių emocinị nestabilumą, agresyvumą, nepakankamą kūrybingumą ir didinti savo profesionaluma, lydimą meile ugdytiniui.

- Sąveikos paradigma sudaro sąlygas pereiti prie mokymosi paradigmos igyvendinimo Lietuvos švietimo sistemoje. Mokinys pasirengia savarankiškam, nenutrūkstamam mokymuisi per visą savo gyvenimą, nes suprastas ugdytinis (mokinys) tampa motyvuotas iš vidaus pažinimui ir tolimesnei savęs atskleidimo ir realizavimo perspektyvai.

\section{LITERATŪRA}

Aramavičiūtè, V. (2005). Auklejjimas ir dvasine asmenybès branda. Vilnius.

Bitinas, B. (2006). Edukologijos tyrimas: sistema ir procesas. Vilnius.

Bitinas, B. (1995). Auklejjimo procesas. Šiauliai.

Bitinas, B. (1990). Bendrosios pedagogikos pagrindai. Vilnius.

Bižys, N., Linkaitytė, G., Valiukevičiūtè, A. (1992). Pamokos mokytojui. Vilnius.

Branson, R. K. (1990). Issues in designing of schooling: changing the paradigm. Educational Technology, 4, 7-10.

Butkienè, G., Kepalaitè, A. (1996). Mokymasis ir asmenybès brendimas. Vilnius.

Čiužas, R. (2007). Pedagogu didaktinès kompetencijos raiška kintant edukacinei paradigmai: daktaro disertacija. Kaunas.

Jacikevičienė, O., Rupšienè, L. (1999). Bendradarbiavimas ir kooperacija ugdant vaikus. Klaipèda.

Jakavičius, V. (1998). Lvadas i edukologijos studijas. Klaipèda.

Jakavičius, V., Juška, A. (1996). Mokyklos pedagogika. Kaunas.

Jakavičius, V. (1998). Ugdymo proceso konceptualios problemos. Kn. Edukologijos idejos Lietuvos švietimo sistemos modernizavimui. Kaunas. P. 81-90.

Jovaiša, L. (1993). Edukologijos įvadas. Kaunas.

Jovaiša, L. (2002). Edukologijos įvadas. Vilnius.

Jovaiša, L. (2007). Enciklopedinis edukacinis žodynas. Vilnius.

Jucevičienė, P. (2007). Besimokantis miestas: monografija. Kaunas.

Jucevičienė, P., Petkūnas,V. (2006). Edukacinès paradigmos kaita IKT diegimo ittakoje: mokytojo ir mokinio vaidmenų ivertinimo kriterijai. Socialiniai mokslai, 2 (52), 65-82.

Jucevičienè, P., Valuckienè, J. (2008). Studiju kokybės sąlygotumas: edukacinès paradigmos raiškos kontekstas. Socialiniai mokslai, 4, 37-51.

Martišauskienė, E. (2006). Fundamentinès ugdymo idejjos ir jų sklaida šiuolaikinèje edukologijoje. Pedagogika, 83, $45-52$.

Martišauskienė, E. (2004). Paaugliu dvasingumas kaip pedagoginis reiškinys. Vilnius.

Merkys, G. (2006). XXI a. iššūkiai Lietuvos mokytojui: esè. Mokytoju ugdymas, 6, 20.

Mičiulienė, R., Palujanskienė, A. (2007). Mokytojų darbo grupių galimybės tapti komandomis. Vagos, 77 (30), 74-82.

Palujanskienè, A., Adamonienė, R. (2004). Profesinė paauglių ir jaunuolių raida. Pedagogika, 74, 129-136.

Palujanskienè, A. (2003). Creativity as the Way of Humanization of Pedagogical Process. In Pedagogy: Theory and Practice. Liepoja: Academy of Pedagogy. P. 201-209.

Palujanskienè, A., Krikščiūnas, B. (2003). Aukštesniosios mokyklos kuratoriaus vaidmuo asmenybės raidoje. Pedagogika, 66, 51-55.

Palujanskienè, A. (2005). Paaugliu agresija kaip charakterio pasireiškimo forma. Pedagogika, 80, 132-140.

Palujanskienè, A. (2007). Pedagogu profesinès orientacijos ir sẻkmès lūkesčiai. Vagos, 75 (28), 45-53.

Palujanskienè, A., Pugevičius, A. (2004). Karjeros samprata pedagogo darbe. Pedagogika, 70, 143-147.

Palujanskienė, A. (2003). Savęs vertinimo ir savigarbos sąsajos ugdyme. Ugdymas. Kūno kultūra. Sportas, 4 (49), 41-47.

Palujanskienė, A. (2003). Socialinių problemų turinčių šeimų paauglių asmenybės vystymosi ypatumai. Pedagogika, 63, 108-113.

Palujanskiené, A. (2006). Suaugusiujų žmonių pasitenkinimas savo gyvenimu. Ugdymo psichologija, 15, 62-71.

Palujanskienè, A., Uzdila, J. V. (2004). Agresija ir konfliktai mokykloje. Pedagogika, 73, 124-127.

Palujanskienė, A. (2006). Vaikų adaptacija mokykloje. Socialinis ugdymas, 1 (12), 84-92.

Palujanskienè, A. (1999). Vaikų psichologinès problemos. Acta Peadagogica Vilnensia, 6, 39—44.

Palujanskienè, A. (2002). Vidinė profesijos mokytojo motyvacija darbo veikloje. Pedagogika, 59, 111-117.

Pudinaite, J. (2007). Subjektu (mokytojo ir mokinio) sąveikos komunikacija. Kn. Proaktyvus mokymasis. Vilnius. P. 281-303.

Šiaučiukènienė, L., Stankevičienė, N. (2002). Bendrosios didaktikos pagrindai. Kaunas.

Šiaučiukènienė, L., Visockienė, O., Talijūnienè, P. (2006). Šiuolaikinès didaktikos pagrindai. Kaunas. 
Uzdila, J. V., Palujanskienè, A. (2005). Valios formavimas — ugdymo esmè. Pedagogika, 80, 79—84.

Večkienè, N., Grebliauskienė, B., Sokolovienė, D., Chrep- tavičienė, V. (1998). Komunikacija ir bendravimas: sampratų santykio problema. Kn. Edukologijos idejos Lietuvos švietimo sistemos modernizavimui. Kaunas. P. 113-136.

\title{
CHANGES IN THE MEANING OF EDUCATIONAL INTERACTION IN THE WORKS OF LITHUANIAN RESEARCHERS IN EDUCATION
}

\author{
Aldona Palujanskienè \\ Lithuanian University of Agriculture, Kaunas, Lithuania
}

\begin{abstract}
Educational changes are a permanent process in the knowledge society. This process is followed by changes in educational paradigm: from empasizing of teaching to the acknowledgement of the central position of teaching in the pedagogical process. Lithuania was under the influence of autocratic culture for a long time and presently follows the tradition of pedagogical effect based on the teaching paradigm in the national education. This prompts to review and expand the paradigm of educational interaction in deeper aspects of schoolchildren's psychics, cognition of the characteristics of growing personality as well as better mastership of the teachers. Hence the transformation of the educational paradigm from teaching to learning faces the sudden challenges: not only the formation of educational environments but also person's low interest and unwillingness to learn something new everywhere and always, as well as to learn purposefully in any possible forms and methods, and not only in a special educational environment but generally in life. When understanding the complex process of teaching paradigm transformation into the learning paradigm in the pedagogical practice, the scientists (Jucevičiené, Petkūnas, 2006; Čiužas, 2007; Jucevičienė, 2007; Jucevičienė, Valuckienė, 2008) analyze the paradigm of interaction which is close to the learning paradigm by its pedagogical provisions and educational content. According to P. Jucevičienè, the paradigm of interaction "acknowledge the free positions of education comparing to teaching paradigm, but it is "more strict" comparing to the learning paradigm" (2007, p. 109). The above mentioned authors emphasize the interaction in the meaning of the selection of methods but the questions arise if the interaction paradigm can be based on free selection of the method. Maybe there are more factors, especially related to the participants of the interaction (educator and schoolchild), which can bring the interaction paradigm to the learning paradigm more closely?

The aim of the article was to systematize the papers of Lithuanian educational scientists on this theme and to reveal the additional possibilities for application of the interaction paradigm. The following tasks were set in order to reach the aim: 1) to describe the conception of the educational interaction in the Lithuanian educational environment; 2) to define the deepened conception of the educational interaction based on the research discussed in this paper. Research methods were analysis of scientific literature.

Therefore the educational interaction can be understood as mutual conception and understanding among the participants of the interaction through their individual characteristics, attitudes and conditions, and as a continuous sequence of pedagogical situations; and in both cases the interaction is an event when its participants will recognize and understand each other so that particular condition of enthusiasm will occur. Hence the educational interaction is analyzed and explained from the standpoint of educational psychology, because according to B. Bitinas the education science is still not ready to form the interaction of the teacher and pupil as self-regulating system and situation is analyzed by the conclusions of educational psychology (2006).

Interactional paradigm is expanded by psycho-pedagogical situations analysed in this article.
\end{abstract}

Keywords: Interaction paradigm; interaction between educator and schoolchild; interactive methods; recognition of schoolchild; mastership of educators.

Gauta 2009 m. sausio 28 d.

Received on January 28, 2009

Priimta 2009 m. kovo 5 d.

Accepted on March 5, 2009
Aldona Palujanskienè

Lietuvos žemès ūkio universitetas

(Lithuanian University of Agriculture)

Universiteto g. 10, Akademijos miest., LT-53361 Kauno r.

Lietuva (Lithuania)

Tel +37065282744

E-mail aldvid@delfi.lt 